\title{
Natural Resources Under Vortex of Simultaneously Elections
}

\author{
Semuel Risal ${ }^{1}$, Johnles ${ }^{2}$, Abner Herry Bajari ${ }^{3}$, Ika Devy Pramudiana ${ }^{4}$, \\ Bartholomeus Padatu ${ }^{5}$ \\ \{ srizal01@yahoo.com ${ }^{1}$, jordanabsalom@gmail.com² ${ }^{2}$ abner.bajari@gmail ${ }^{3}$, \\ ik.pramudiana@gmail.com ${ }^{4}$, blpadatu@gmail.com $\left.{ }^{5}\right\}$
}

Polytechnic Malinau, North Kalimantan, Indonesia ${ }^{1}$, Polytechnic Malinau, North Kalimantan, Indonesia ${ }^{2}$, Universitas Cenderawasih Jayapura, Papua, Indonesia ${ }^{2}$, Universitas Dr. Sutomo, Surabaya, Jawa Timur, Indonesia ${ }^{4}$, Sekolah Tinggi Ilmu Administrasi (STIA) "AAN" Yogyakarta, Indonesia ${ }^{5}$

\begin{abstract}
The political phenomenon that develops in the democratic order in Indonesia shows that local election (Pilkada) has become a "political industry" that requires large capital for investment. This research explores the high cost of contest local elections, which is then used by the cukong to become a partner for politicians in hunting down rent through the Pilkada. Our findings show that the Pilkada becomes an arena for battle between cukong, and regions that have abundant natural resources are contested by large local and national cukong to finance all the needs of the candidate's campaign. They control natural resources, so they are the ones who decide who is the regent, who is the governor. Natural resources, especially coal mines, are occupied emphasize as one of the main sources of driving the political machine, which has an impact on bad environmental management practices. A large number of political party leaders and several businessmen who own mining, large-scale plantations have contributed to the destruction and overexploitation of nature. Therefore, the issue of natural resources must be included in the agenda of local and national political processes and break the chain of political cukong with transactional natural resource rulers.
\end{abstract}

Keywords: Pilkada; Political Cukong; Natural resources; Political Industry; Ecological Disaster.

\section{Introduction}

The local elections (Pilkada) are one of the national political consensuses, which is one of the important instruments of governance at the local level after decentralization and regional autonomy. Indonesia's transition to a democratization era began with the fall of the authoritarian New Order regime in 1998 under the leadership of President Soeharto. After the reign of the New Order, the hegemony of the central government also shrank, but it was the turn of the local political elites and entrepreneurs to compete to gain control over resources at the local level. During his reign of approximately 32 years in power, Suharto was in control of power with very tight control with a centralized system of government, including in political affairs and control of natural resources.

The issuance of Law No. 22/1999 on Regional Government, ended the centralized regime towards decentralization and regional autonomy which was changed to Law No. 32 of 2004 concerning regional government. The election for governors and regents/mayors, previously 
elected by the Regional House of Representative (DPRD), has changed with the issuance of Law no. 32 of 2004, which is the regime of law that regulates local elections. After being enacted for a decade, Law 32/2004 has been revised and replaced with Law Number 23 of 2014 concerning Regional Government which is in effect until today.

Since 2005, local elections were introduced until 2015, it began to be held simultaneously as a solution to overcome various problems previously faced, especially the election costs disbursed from the APBN and APBD were so large. However, direct elections opened up opportunities for ambitious local politicians and businessmen to build new networks of power and take control of local resources [1]. The problems encountered in almost all local elections are never devoid of 'money politics' starting from the nomination process, handing over money just before candidate registration, and giving dowries. In addition, the campaign costs used by candidates in the contestation are so expensive.

So that money politics in the local elections becomes one of the causes of the high costs incurred by candidates. The oligarchy of the super-rich in power keeps this electoral democracy under its interests, by providing money for the candidates and it has championed in exchange for strengthening its economic power at the local level. Elections and local elections are always filled with money politics to 'buy' voters' votes. Simultaneous regional elections also failed to prevent the spread of money. This predatory oligarchy can mobilize a decentralized patronage network, and competing coalitions, including involving thugs and paramilitary networks [2].

When viewed from a decentralization perspective, local elections are a breakthrough for the process of consolidating democracy at the local level, because elections can open a wider space for participation for the community in the democratic process to determine political leadership at the local level. In addition, this system also opens opportunities for people to better actualize their political rights without having to be reduced by the interests of political elites, such as when the representative democracy system applies. Even elections can be said to be an ideal system if in the process of implementing direct democracy it shows the manifestation of sovereignty in the hands of the people, a regional head will be produced who will receive direct support from the people (including cukong), money politics can be minimized because it is impossible to bribe millions of voters. So that the elections are actually part of the local political system.

Several studies on political theory and models explain local politics [3]; [4]; [5], but these create gaps in our knowledge of local politics because broader theories and models are largely not tested in different contexts. In this paper, we explore natural resources as a basis for fighting candidates amid the high cost of political campaigns at the local level. The impact of high spending on candidates' political costs in local election in almost all regions in Indonesia, forced candidates to seek sponsors. Where the candidates spend large, although relatively different in terms of the amount of money spent in the struggle for power seats. Gary J. Jacobson in his study of the role of money in elections [6], and Jacobson and Kernel's study of the strategic concept of candidates [7] reviewed the importance of money and candidates in elections.

Among the many factors essential for a democratic system to function well, there is little that is widely debated about campaign finance in general elections (elections). For some, money in the political arena serves as a form of expression of free speech as well as an effective instrument for informing voters and building an inclusive democracy. However, for others, the uncontrolled use of money in politics can erode the function of democracy because it can lead to excessive campaigning, unequal access to power, and politicians who are tied to special interest groups [8]. In practice, nearly every country with political pluralism has adopted some type of political finance regulation, ranging from the obligation to inform the source of the 
contribution and the authority to disclose the donation, to the formula for limiting campaign contributions and/or spending.

Perludem revealed that 4 sources of expenditure caused the high cost of local elections, namely (1) The cost of the regional head nomination, (2) campaign finance for image politics, (3) The cost of consultation and winning surveys, (4) Money politics [9]. Moreover, of the Ministry of Home Affairs R\&D study showed that to become a Mayor / Regent requires costs of up to 20-30 billion, while to become a Governor ranges from 20-100 billion. In fact, the cost of becoming a regional head is greater when compared to the cost of becoming a legislative member which only reaches Rp. 300 million-6 billion [10]. The amount of cost required is not balanced with the capabilities of the candidates for Regional Head, so they have to look for coffers of money through mining and plantation permits.

The Mining Advocacy Network [11] notes that the land and waters of the Indonesian archipelago have been plotted by 10,388 IUPs or 44 percent of the country's area. In East Kalimantan, mining permits always increased in the period before and after 2005, 2008, and 2013 Samarinda Pilkada. Before the 2005 Samarinda Pilkada, only two mining permits were found, but they increased after the 2005 Pilkada to 76 permits. Until 2017 there were 1,433 permits in East Kalimantan. This figure continues to increase until the 2019 election and simultaneous regional elections in 2020.

The large number of IUPs in East Kalimantan (Kaltim) has resulted in high exploitation of natural resources, which has resulted in severe environmental degradation and the marginalization of local residents from economic resources owned long before the presence of coal mining companies. Even further, the impact of the mining company is the collapse of the indigenous community of local people who are the legacy of their ancestors who have long lived in the area which is now a mining area.

Now, East Kalimantan is still relying on the economy on cutting down trees for HTI and $\mathrm{HPH}$, dredging coal, and opening oil palm plantations. After the division of North Kalimantan, the area of East Kalimantan became 12.7 million hectares. From that figure, based on data from the East Kalimantan Forestry Service, 46 percent or the equivalent of 5.2 million hectares is allocated for mining. Meanwhile, the plantation area is only 3.37 million hectares. No more than 4.27 million hectares is the living space that must be divided into houses of worship, hospitals, and schools, roads, and markets, as well as garden parks and settlements for a population of 3.4 million.

Pilkada is nothing more than an arena to seize power and position for a handful of elites and politicians to continue to accumulate financial capital for themselves, their groups, and political parties. More than that, this five-year party is also momentum for large-scale landbased businessmen who are looking for political guarantees to perpetuate their businesses in mining areas. Another indication is that there are many problematic mining business permits. [12] identify permission problems up to now there are as many as 3,772 IUP. He contained various cases, ranging from non- $\mathrm{CnC}$ (clean and clear) status, overlapping permits, noncompliance with taxes, and not a few suspicions of corruption involving regional heads as licensors. Meanwhile, today's political contestation costs such a large amount. The political costs of becoming a mayor or regent in Indonesia can cost between 20 to 30 billion rupiah, while for governor positions it is between 20 and 100 billion rupiah.

Meanwhile, the assets of politicians who run for regional heads are only Rp. 6.7 billion rupiah. Then where did the lack of funds come from? In this context, this article explores the high costs of pilkada contestation, simultaneous Pilkada funding sources, and the extent to which natural resources are a source of funding in the pilkada. 


\section{Research Method}

This study uses a content analysis approach, which is a research approach that focuses on an in-depth investigation of an object. The data was collected by using the purposive sampling technique with a focus on natural resources as the basis for the contest in the Pilkada. After conducting a literature review, we then conducted semi-structured interviews related to the simultaneous regional elections in East Kalimantan by conducting interviews with entrepreneurs as donors, success teams, and candidate pairs for regents/mayors. Interviews were conducted to reveal the informants' attitudes and perspectives to obtain important information about events or realities related to the holding of direct regional head elections. The focus of the questions addressed to the informants was emphasized on four themes: 1) the impression of the informants about the high-cost pilkada; 2) how much money is needed in the election contestation; 3) sources of funds to finance the power struggle in regional elections; 4) what is the potential of natural resources in the area.

It should be noted that in the context of contemporary social science, texts reflect a methodological strategy, so we detailed the questions through an interview guide, from which the data were collected and interpreted. To explore the various issues outlined above, the first part of this article contextualizes the high-cost Pilkada. Then, the methodological design of the investigation is detailed, which opens the space for debate about the four dimensions explored during the interview, highlighting options for dealing with each empirical dimension with the relevant literature, to avoid previous common reasons about references. The final topic of this paper reflects on the phenomena and perspectives echoed in the previous section, points to research findings, and reflects on the extent to which natural resources are a source of pilkada funding. The data obtained were analyzed using an interactive analysis model consisting of four stages, namely data collection, data reduction, data presentation, and conclusion.

\section{Result and Discussion}

East Kalimantan is the center of the coal industry in Indonesia. There are thousands of open-pit mines in this area and most of them are illegal mining. New mines continue to be opened, while old ones are abandoned once coal reserves have been depleted. In fact, according to Indonesian law, mining companies are required to close mine pits that are no longer used and carry out reclamation and restoration of mining environments. However, many companies violate existing regulations. This has continued extensively in all mining areas in East Kalimantan and the coal-rich provinces of Indonesia.

The exploitation of natural resources triggers the destruction of forests in Indonesia and brings the country to the top of the list of global carbon emitters. The destructive power of the mine is getting worse with each regional election event until now. We investigate the intricacies of the pilkada as a battle between "political cukong" pushing for the issuance of licenses for mining companies, as this large-scale land-based industrial investment tends to increase the number of permits in the years leading up to, during, and after the Pilkada. In several cases, we found that there was a direct relationship between the issuance of IUPs and each approach to electoral political events in the elections. This finding shows that the situation which emphasizes the existence of rent-seeking practices is deeply rooted in the power struggle through the succession of the regional head elections which has an impact on environmental deterioration and forest destruction. 
Data from the 2018 East Kalimantan Provincial Mining Service shows that by 2020, there are 1,404 Mining License (IUP) issued by district/city governments in East Kalimantan. Thousands of coal mining companies operating in East Kalimantan can be seen in figure 1

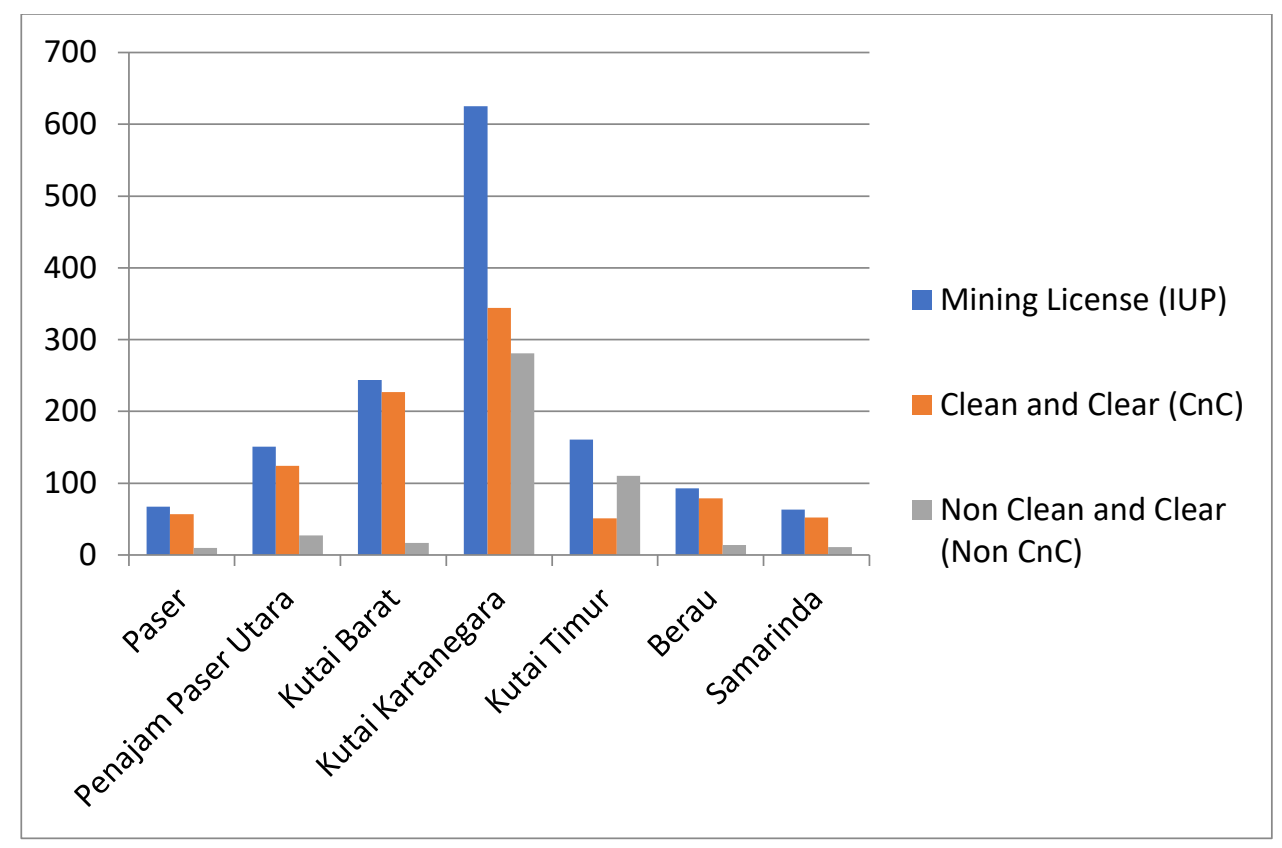

Fig 1. Mining License (IUP) in East Kalimantan Province. Source: [13] (data processed)

Figure 1 shows that $70 \%$ of regencies/cities in East Kalimantan have opened the widest possible IUP for coal mining companies. Of the 1,404 existing IUPs, the licenses were issued within a period of 15 years, namely 2001-2016. Even the issue of a mining business license (IUP) which has a clean and clear ( $\mathrm{CnC}$ ) and nonclean and clear (non-CNC) status seems to have never been resolved. Based on the data in Figure 1, shows that there are 934 IUPs with $\mathrm{CnC}$ status, while those with non $\mathrm{CnC}$ status are 470 IUPs. As for the IUP which has not yet secured the $\mathrm{CnC}$ certificate due to several factors, such as not fulfilling the obligation to pay fixed fees, royalties, and taxes. In addition, there is an overlap of land so that it has not placed a reclamation guarantee with the bank. Based on the instruction of the Minister of Energy and Mineral Resources (ESDM) Regulation Number 43 of 2015, it is stated that all non-CnC IUPs must be revoked, but until now, hundreds of companies with non-CnC status are suspected to have not been revoked by the Provincial Government of Kaltim until the authority is withdrawn to the Center.

Apart from 1,404 IUPs in East Kalimantan, there are 30 Coal Mining Concession Work Agreement (PKP2B) permits issued by the central government with an area of 990,449.25 hectares. Mining business permits in East Kalimantan remain uncontrolled so that local, national, and international corporations are plots of land, forests, for mining businesses. The total area of the mining area is cultivated by 1,404 mining business license holders with an area of $4,011,881.75$ hectares, in table 1 . 
Table 1. IUP recapitulation based on East Kalimantan Province Regency/City until 2020

\begin{tabular}{lr} 
Regency / City & \multicolumn{1}{l}{ Area $($ Ha $)$} \\
\hline Paser & $123,200,19$ \\
Penajam Paser Utara & $260,422.60$ \\
Kutai Barat & $1,445,297.00$ \\
Kutai Kartanegara & $627,617.63$ \\
Kutai Timur & $1,247,153.02$ \\
Berau & $281,026.73$ \\
Mahakam Ulu & - \\
Balikpapan & - \\
Samarinda & $27,164,58$ \\
Bontang & - \\
\hline East Kalimantan Province & $\mathbf{4 , 0 1 1 , 8 8 1 . 7 5}$ \\
\hline Source: [13] (data processed)
\end{tabular}

This mining permit grew after the authority was handed over to districts/cities. So that the total area for mining amounts to 5.2 million hectares and most of it overlaps due to land conversion. The transfer of land functions is also related to the interests of political elites at the local level and how local politics is carried out through patronage relationships, in particular between politicians and businessmen. The relationship between people who hold political positions and people who have wealth and business interests, where they provide funds to political officials to use their power and influence to provide various benefits, both legal and illegal, which will facilitate their business activities.

Entrepreneurs who make donations to politicians expect rewards later, either in the form of budget allocations, projects, or business guarantees. In many regions, district heads use their power as "rent-seeking" or benefit from policies they make. In this case, the regent in power can restructure government institutions in such a way that he gains direct, exclusive, and full authority over state assets. As a result, the Regent can control the practice of bribery in the bureaucracy and can provide rewards or sanctions for the parties involved, both from the politicians and bureaucrats, as well as from the private sector.

In areas that have forest areas, the public resources that can be accessed by the political elite are not only the APBD but also the forest area itself. The process of forest function conversion is closely related to politics. So that the link between the pilkada and deforestation, namely the political logging cycle, where there was an increase in IUP before and after the election so that the increase in deforestation was in line with the expansion of new regions. Those who are familiar with the process of forest function conversion permits will admit that the long procedures and strict requirements for forest conversion are, in practice, an opportunity for corruption. This practice involves not only actors at the local level but also actors at the national level.

In relation to natural resources as a source of funding for the elections, we conducted research in five regions in East Kalimantan. We found that in Kutai Kartanegara district, East Kalimantan province, in 2010 or right when the district was holding Pilkada, the local government issued 191 new Mining Business Permits (IUP), whereas a year earlier there were 
only 93 IUPs. In Berau District it is no different. Along with the 2010 regional elections, an increase in the number of permits occurred in the 2009-2012 period. In 2009 there were 68 KPs with a land area of 228,060 . Increased to $92 \mathrm{KP}$ in 2012 with an area of 381,026 ha. Likewise in West Kutai District, there has also been an increase in the number of permits issued by the regent. Pilkada in that area was held in 2011. As a comparison, in 2007 there were only 15 KPs in that area and increased in 2009 to $138 \mathrm{KP}$.

In 2012 the number increased significantly, to $267 \mathrm{KP}$ with a land area of 1,445,297 ha. In Penajam Paser Utara District, this trend is also evident. Pilkada in 2013, the number of permits issued per December 2012 reached $160 \mathrm{KP}$ with a land area of 260,422 ha. Whereas in 2009 in that area the number of KP issued was $36 \mathrm{KP}$ with a land area of 86,307 ha.

Local political elites in areas rich in forest resources raise funds and raise and maintain support from voters. The impact of patronage on forest resources and land-use change is the strengthening of the relationship between patronage and land-use change.

After the 2010 Pilkada, the number of mining concessions increased significantly in resource-rich districts, including in East Kalimantan. This trend continued into the 2018 Pilkada until Jatam and the number of other organizations estimated that the number of mining permits issued across Indonesia exploded from 750 permits in 2001 to 10,000 in 2010 [11]. In the 2015 regional elections, many candidates were competing. need external sources to fund their campaign. The capital required to win a seat for mayor or regent is estimated at around Rp. 2030 billion, while for the seat of the governor, candidates need to prepare campaign funds of up to Rp. 100 billion [12]

The relation between authorities and entrepreneurs is key actors' role in the system of exploitation of coal resources, one of the commodities mines since long been a problem in the province of East Kalimantan. Formal actors, namely the rulers, work as facilitators to open access to capitalization of energy and local resources, as well as the strength of the informal economy, namely entrepreneurs playing the role of executors in the field in reducing the space for the country's orientation.

So that there is a strong connection between local political figures and entrepreneurs. This condition gave birth to clientelistic power from the transaction process of formal and informal institutions so that the transformation of the relationship between the two actors is a consequence of changes in the distribution of power and resources as well as the emergence of the phenomenon of local power under the shadow of the power of the State that dominates the mining governance system in East Kalimantan.

One of the Districts in the coastal area of Kutai Kartanegara Regency, namely Samboja District with an area of $1,045.90 \mathrm{~km}^{2}$, is surrounded by 92 coal mining permits. Number 91 permits status Permits Mining (IUP) issued by the district government and one license status Coal Mining Agreement (PKP2B) issued by the Ministry of Energy and Mineral Resources. Most of the permits were issued at the time of approaching regional head elections. The Legal Coordinator for the Mining Advocacy Network (Jatam) said that most IUPs were issued in the period 2004 to 2007.

This period of license bubble up coincided with the political events of Kutai Kartanegara (Kukar) and was related to the capital of the 2004 Kukar Pilkada. About 50 percent of Samboja's area is included in the IUP area. Of the IUP area of around $500 \mathrm{~km} 2$, about 20 percent have been exploited, about 50 percent of them are in the exploration stage and 30 percent are in the status of general investigations. Mine Samboja invasion lasted until 2009. This includes an increase in the IUP status of a public inquiry to discover, from exploration to exploitation and from exploitation into production. Last IUP published 2009. However, permission p Increased exploitation permit status queue at the Department of Mines Kukar. No wonder Samboja has 
experienced frequent flooding in the last 5 years. Besides, because of forest function change due to mining invasion. Several cases of the Samboja flood were caused by broken coal embankments. Settlements, agricultural land, educational facilities inevitably fell victim to the disaster. Floods not only caused material losses; several residents even lost their lives because they were dragged by the flood currents.

In West Kutai District, with a total district area of 3,162,800 ha, with a classification of $2,344,589$ ha as forest areas in 2010. Over the past ten years, there have been major political competition between Rama Asia (Bupati 2001-2006) and Ismael Thomas (Deputy Regent 20012006) in West Kutai. In the 2001 pilkada, he ran as a candidate for district head and won the election by being promoted by the PDIP and PAN coalition. Meanwhile, Rama at that time was promoted by a coalition of the Democratic Party, the Prosperous Peace Party (PDS), and the Pioneer Party. In 2011, Ismael Thomas again ran in the pilkada and effectively lobbied the Democratic Party to leave Rama and ask the party to support him. A number of companies are the main supporters of Ismael Thomas, including Sendawar Media, PT. Teras Purai Tanajaya played an important role in financing Ismael Thomas's campaign.

The Legal Coordinator for the Mining Advocacy Network (Jatam) said that "Edy Gunawan was placed by IT to obtain coal concessions through his subsidiary, namely a coal mining company called PT. Equatorial hornbills (BEK). During Ismael's first tenure, PT BEK was granted a large-scale license to mine coal, and the company is closely associated with IT. At the beginning of its establishment in 2010, the book value of PT. The BEK is recorded as only Rp. 5 billion, but when it was sold to Geo Energy Group in 2011, the company's book value reached more than Rp. 1 trillion. It is no secret that the profits from the sale of PT. BEK is used by IT for political capital.

For perpetuates patronage in Kutai Barat after his term expires in the period both in April 2016, IT supports FX Yapan as a candidate for the West Kutai regent for the period 2016-2021. FX Yapan is the Chairman of the three-term DPRD who has a big role in winning IT because he was twice the successful Team Leader in the regional elections in 2006 and 2011. FX Yapan, who is paired with Edyanto Arkan, has won the simultaneous regional elections on December 9 2015 which was officially inaugurated on December 20 April 2016 replaced IT. The next IT target is to run for the East Kalimantan Governor Election which will be held in 2018. IT, which incidentally is the Chairperson of the West Kutai Regency PDIP DPC, proclaimed itself to be a candidate for the Governor of East Kalimantan but the PDIP chose to carry the East Kalimantan regional secretary Rusmadi Wongso paired with Saparuddin who served as the Head of the East Kalimantan Regional Police.

The election for the Governor of East Kalimantan in 2018 is interesting to observe because it is without an incumbent and becomes a battle for the Regent / Mayor, former regents, bureaucrats, and party leaders. Candidates who have sprung up are dominated by former Regents / Mayors and Active Bupati / Deputy Regents including the Mayor of Samarinda City who is also the chairman of the DPD Kaltim Democratic Party H. Syaharie Jaang and is paired with Awang Ferdian Hidayat, a member of the DPR from PDIP who incidentally is the son of the former East Kalimantan Governor Awang Farouk Ishak, who served two terms. Then the former Bontang mayor Andi Sofyan Hasdam paired up with Nusyirwan Ismail, who was still active as deputy mayor of Samar Inda 2018 when running for office.

Next, is Isran Noor who is a two-term former East Kutai Timur and has served as Acting Chairman of the Indonesian Justice and Unity Party (PKPI) in 2015-2016 replacing Sutiyoso paired with Hadi Mulyadi who is still registered as a member of the DPR-RI from the Prosperous Justice Party (PKS), but left PKS in 2019 and became Chairman of the Regional Leadership 
Council (DPW) of the East Kalimantan People's Wave Party (Gelora). And Rusmadi WongsoSaparuddin's partner was promoted by the PDI-Perjuangan.

Before the names of the four candidates emerged, one big name had already risen to the surface and was already believed to be elected, namely Rita Widyasari, the former Regent of Kutai Kartanegara who was involved in the KPK bribery case. As long as his name has flown, political power in East Kalimantan has been close to Rita. The four candidates who competed in the 2018 Pilgub benefited when the KPK put Rita in prison. These four candidates are related to the mining business. Some have direct ownership; some are in the form of support and donors. Even in the implementation of the 2018 regional election debates, none of the four candidate pairs was concerned about the environmental crisis in East Kalimantan. No one also dared to promise to close the mine pits which had claimed dozens of victims, and no one spoke of how East Kalimantan would get out of the mining problem. So that the commitment to saving the environment escapes the attention of the candidates.

The 2018 East Kalimantan (Kaltim) Pilgub, won by Isran Noor, who was the Regent of Kutim, has issued mining permits for limestone, gypsum, clay, sand, coal, and gold since 2009. A total of 154 permits covers an area of 16 times the city of Samarinda. As many as $66 \%$ of the permits were issued when they just served as Regent of Kutim in 2009. Even Isran Noor was close to Governor Awang Farouk, and they paired up to lead Kutim Regency in 2006-2008, but both of them were opposite in the 2018 Pilgub in East Kalimantan, because Awang Faroek Ishak his son as a candidate for deputy governor.

The political Ijon for the East Kutai regional election is important because two former regents in this district have recently served as the Governor of East Kalimantan, Awang Farouk Ishak (2008-2018), and Isran Noor (2018-2023). When Isran Noor served as Regent of Kutim in 2009-2015, mining permits, including those in Sangkulirang Mangkalihat, reached 383 or an average of one permit per week. The peak was during the approaching period for the 2009 pilkada and after the 2009 Pilkada, the number of IUPs issued was 68 licenses and became 154 in 2014 and 161 in 2015.

The licensing mode related to the regional head elections is called the Corruption Eradication Commission (KPK) as a way to gain political funds. Transactional politics involving business people and local officials. The transaction can be in the form of support for winning campaign services. This is corroborated by the KPK's Research and Development report entitled "Study of Potential Conflict of Interest in the 2015 Pilkada Funding" which describes the costs of becoming mayor/regent reaching Rp. 20 - Rp. 30 billion, or even Rp. 20 billion to Rp. 100 billion to become governor.

These candidates for regents and governors will come up short if they refer to the State Administrators' Asset and Wealth report (LHKPN) which reveals that their wealth averages only Rp. 6,7 billion. This high-cost electoral system triggers mining licensing transactions during regional elections. The Mining Advocacy Network (Jatam) calls this phenomenon a political bond.

Various academic literature reviews that money plays an important role in Indonesian politics so that the organic relationship between money and politics describes Indonesian politics as dominated by patronage and clientelism [14]; [15]. Since the simultaneous Pilkada in 2015-2018, the large amount of costs required by regional head candidates in their candidacy in the Pilkada has made them seek and receive financial donations, which has the potential to create a conflict of interest when elected as regional head.

In Penajam Paser Utara and Kutai Kartanegara districts, we found that for mining, usually per 100 ha of land that the permit is issued for, entrepreneurs spend up to Rp 2 billion. So, for 
200 ha of land, there is Rp. 4 billion that must be spent by entrepreneurs, which on average is given in the form of cash.

Based on data from the Ministry of Energy and Mineral Resources, of the 10,922 IUPs in Indonesia, 4,880 have non-C \& C status. Then, from the data from the Directorate General (Dirjen) of Taxes, the 10,922 IUPs came from 7,754 companies. A total of 3,202 had no identification of their NPWP. And for the entire NPWP, many do not report their SPT. From data from the Ministry of Forestry (Kemenhut), 10,922 IUP plus 111 Contract of Work (KK) companies and Coal Mining Exploitation Work Agreements (PKP2B) are located in conservation forests, protected forests, and production forests.

The average non-tax state revenue (PNBP) underpayment was $72.89 \%$. Of the 8 provinces, the total 2011-2013 PNBP underpayments amounted to Rp 331 billion and the US \$ 546 million. As a result, the potential for state financial losses from the mineral and coal sector reached Rp 35.6 trillion and the US \$ 1.79 million. This amount is calculated from the 2011 2013 PNBP receivables, potential lost tax revenues, state losses based on verification of mineral export data, and potential unpaid royalties, as shown in table 2.

Table 2. Potential State Losses from the Mineral and Coal Sector 2011-2013

\begin{tabular}{ll}
\multicolumn{1}{c}{ Potential Losses } & Amount \\
\hline PNBP Receivables for 2011-2013 & $\begin{array}{l}\text { Rp. 331 billion } \\
\text { and the } \\
\text { ÚS \$ 564 } \\
\text { million }\end{array}$ \\
$\begin{array}{l}\text { The potential for lost tax revenue due to differences in production } \\
\text { data from the Ministry of Energy and Mineral Resources and BPS }\end{array}$ & Rp. 28.5 trillion \\
$\begin{array}{l}\text { Potential state losses based on verification of mineral export data } \\
\text { for 2010-2012 from 198 mineral mining companies }\end{array}$ & $\begin{array}{l}\text { The US \$ } 1.2 \\
\text { Potential state losses are based on verification of mineral export } \\
\text { data in 2011 from 180 mineral mining companies }\end{array}$ \\
$\begin{array}{l}\text { Potential royalties that are not paid by coal and mineral } \\
\text { companies }\end{array}$ & $\begin{array}{l}\text { The US \$246 } \\
\text { thousand }\end{array}$ \\
\hline
\end{tabular}

Source: [10]

The KPK found differences in data on state income from the coal mining sector. The difference in data was found by the KPK from the Ministry of Energy and Mineral Resources, the Ministry of Trade, the Directorate General of Customs and Excise, and others. Meanwhile, the results of the Indonesia Corruption Watch (ICW) study regarding the mineral and coal business in Indonesia, found that the ICW research team during the 2006-2016 period found indications of unreported export coal transactions amounting to the US \$27.062 billion or equivalent to $\mathrm{Rp} 365.2$ trillion. This has an impact on the indication of state losses both from the obligation of coal companies for income tax and royalties of Rp. 133.6 trillion [16]. The difference between the data from the Ministry of Energy and Mineral Resources and the data owned by the relevant ministries could be an opening for corruption.

The development of coal production and exports in Indonesia has increased significantly in the last 5 years, both the number of exports and coal production from year to year has increased significantly. This shows that there are numbers of exports that are not recorded or can be said to be illegal. The amount of this export can be categorized as a state loss due to nonpayment of royalties and revenue taxes and other value-added taxes. The average excess of coal 
exports from total production per year is around 24.57 million tons with a total value of US \$ $1,242,352.24$ or equivalent to Rp. 12,423 billion assuming the exchange rate of 1 USD $=$ Rp. 10,000 . Not all of the national coal production is exported, but coal sales are required to meet domestic needs (domestic market obligation).

The validation result of the realization of the average amount of coal per year for domestic needs (2008-2014) is 57.45 million tons [17]. The number of exports that exceeds the amount of coal production indicates that there is an amount of coal production that is not officially recorded or not reported by the owner of the Mining Business Permit (IUP). As a result of comparisons between data from the Ministry of Energy and Mineral Resources and the World Coal Institute (WCI), the KPK found that there had been a difference between the production and export of Indonesian coal in 2014, where the total production was 109.81 million metric tons (MT), while the exports amounted to 131.94 million MT. This means 22.13 million MT of unrecorded coal and is an illegal export.

This is by [18] statement that mining governance has not been implemented properly which is indicated by: (i) weak coal mining production data, and (ii) there is a difference in production data between the Directorate General of Mineral and Coal (Ditjen Minerba), The Ministry of Energy and Mineral Resources with the Central Bureau of Statistics (BPS). Actually, the task of recording production data, domestic sales, and exports is carried out in stages from district/city to province and minister, the provincial government to district/city and minister as regulated in Article 7 of Law no. 4 of 2009 concerning Mining and Coal. Central BPS receives data on production, domestic sales, and exports of coal from the Ministry of Energy and Mineral Resources or reports from provincial and district/city BPS. Central BPS also obtained coal export data from the Ministry of Trade. If coal export data is large and unrecorded and coal production tends to increase (an average of 200 million tons per year with an income of around Rp. 22 trillion), it will accelerate the rate of coal extraction so there is concern that it will threaten its sustainability level.

Survey of Potential Conflict of Interest in Pilkada Funding on the consequences of donors' donations made by the 2018 KPK, out of 171 regions that held Pilkada, and 34 people spent their funds exceeding the total assets owned. In 2017 there were 5 people and in 2015 there were 46 people. In fact, as many as 20 respondents admitted paying dowries to political parties ranging from 50-500 million / seat, which is an agreement between the Party and the pair of candidates for the regional head. Meanwhile, in the LHKPN report, the average total assets of a candidate for Regional Head only reached Rp. 6.7 billion. In fact, there are 3 people who have assets of Rp. 0, - and 18 other people have negative assets. The amount of pilkada costs that are not supported by the ability of the pair of candidates' assets, prompts prospective regional heads to seek sponsors who are dominated by entrepreneurs. Donors who come from entrepreneurs/business people expect returns in the form of ease of business licensing, ease of participating in government project tenders, and security in running a business [12].

Our analysis of a database of government-issued permits, interviews, and a number of documents, shows that political cukong are widespread in all districts and are primarily targeted at resource-rich districts. Whispers from mining and plantation companies, in order to perpetuate business access, seem stronger than civil society's relentless movement against efforts to destroy forests and take over the land. Extractive political institutions give rise to economic institutions with the character of enriching a handful of people who manipulate elections to perpetuate their power [19]. This condition tends to occur in rural areas and forest areas where agribusiness and extractive industries are prominent. So that the most significant threats to Indonesia's forests that have emerged in recent years are actually a stern warning that cannot be ignored. 
In managing natural resources, especially in the mining sector, regulations have been issued, namely Law (UU) No. 4 of 2009 concerning Mineral and Coal Mining. This regulation is intended so that the implementation of coal mining provides maximum benefit for the prosperity of the community and the area where the mining is carried out. However, the dishonest behavior committed by mining companies has caused losses to the state and society. This dishonesty is evident from the production report which is exported with the explorationexploitation volume report in the mining area. The value of state losses due to the manipulation of coal production and export reports is calculated based on the types of state revenues that must be obtained from coal production as stated in Law (UU) No. 4 of 2009 concerning Mineral and Coal Mining.

The phenomenon that occurs in every election, both the Presidential Election, the Governor, and the Regent Election requires a huge amount of money. There are two sources of funds that are often used, namely: first, own capital, and second, sponsors or cukong. But what's interesting is political sponsors or supporters. Because it cannot be denied that businessmen are willing to spend tens to hundreds of billions of rupiahs as political costs to support their candidates to win the power struggle in the Pilkada. Interestingly, it is an area that has abundant natural resources that are contested by large local and national cukong to finance all the needs of the candidate's campaign. Natural resources are positioned as one of the main sources of driving the political machine, which results in poor natural resource management practices.

Access to finance from the mining industry encourages politicians to spend money to beat other candidates in Pilkada battles so that candidates with minimal capital find it difficult to break through local political walls. Given the high cost of election campaigns in Indonesia, candidates without strong ties to voters find it difficult to avoid offers of campaign capital from political cukong. These high election costs are an important reason why democracy in Indonesia does not result in restrictions on domination by economic elites [15] so that the quality of local democracy is threatened in areas where control over the main resources in the local economy controlled by several big players [20]. The expansion of the coal mining industry in East Kalimantan has a negative impact on the socio-economic life of the community [21]; [22] and opens fertile fields for the practice of corruption. The fight against oligarchic interests supported by the mining industry, and fighters for the preservation of the environment and living space for villagers, clearly requires stronger efforts and encouragement from elements of civil society and oppressed citizens regarding the damage caused by extractive industries to the environment and livelihoods. villagers.

The existence of a gap between the financial capacity of the candidates for Regional Head and the costs incurred opens up opportunities for candidates to seek and receive additional funds. So, this is where the entry point for "political cukong" to take advantage of the momentum in the Pilkada. Entrepreneurs are willing to spend tens to hundreds of billions of rupiahs as political costs to support their candidates to win the power struggle in the Pilkada. The interesting thing is that regions that have abundant natural resources are being fought over by the big cukong, both local and national, to finance all the needs of the candidate's campaign. Natural resources are positioned as one of the main sources of driving the political machine, which results in bad environmental management practices. So, it appears that the relationship between electoral politics, private business interests, and environmental damage is very strong.

However, behind the dirty political portraits, expectation still exists. There is some evidence to suggest that candidates who are more concerned with the interests of the people or the public stand a chance of winning. Those who succeed in winning over the people's hearts, and can get rid of entrenched corporate interests. They carry out campaigns with popular programs and policies, such as subsidies for education and health. They also did not hesitate to 
refuse corporate persuasion when taking office. For example, President Joko Widodo (Jokowi), who began his political career as Mayor of Surakarta, Central Java, then became Governor of Jakarta. Leaders like Jokowi is very unlikely to appear in places where the economic pattern that has concentrated on one or a few sectors $u$ all [15]. To be able to support this situation by breaking and breaking the chain of hegemony conspiracy of mafias in the regions, much bigger intervention is needed. This was not only done by the KPK, but also by civil society participation. Several progressive developments in the field of law have recently been able to support work against oligarchic politics, clientelism which is full of corruption.

\section{Conclusion}

The large gap between cost and amount of wealth meant that anyone who had to run for office would think hard about getting money. Indeed, not all funds have to come from the personal pockets of the candidate, but campaign funds allow sources of funds from other sources, namely the supporting party or coalition as well as legal donations from other parties. This is where a potential conflict of interest problem occurs because what happens is mining companies offer the candidate a sum of funds, and vice versa. In return, if later in power, those who have been capitalized are asked to facilitate business licensing as "political bonds".

Our analysis concludes that, first, with rapid growth in the last 20 years, the coal sector has become one of the main sources of political finance in Indonesia, both at the national and regional levels. Money from the coal mining business then fills the funding needs of candidates in the regional elections. Mining entrepreneurs control natural resources, so they are the ones who decide who is in charge. Second, the sale of coal mining business permits ahead of the Pilkada and a year after the Pilkada is over. Third, natural resources are a source of funding for the Pilkada which requires high costs. Fourth, the rulers and politicians are involved in exploiting natural resources and turning regional elections into a political industry. So that the ecological crisis is getting worse in East Kalimantan.

\section{Acknowledgments}

We would like to thank all research participants for giving their time and sharing their perspectives for informing this paper. Every mistake is our responsibility.

\section{References}

[1] E. Collins, Indonesia betrayed. 2007.

[2] Vedi R. Hadiz, Localising Power in Post-Authoritarian Indonesia: a Southeast Asia Perspective. California: Stanford University Press, 2010.

[3] M. J. Marschall, "The Study of Local Elections in American Politics," in The Oxford Handbook of American Elections and Political Behavior, 2010.

[4] J. Trounstine, "All politics is local: The reemergence of the study of city politics," Perspect. Polit., vol. 7, no. 3, 2009, doi: 10.1017/S1537592709990892.

[5] M. Marschall, P. Shah, and A. Ruhil, "The study of local elections," in PS - Political Science and Politics, Jan. 2011, vol. 44, no. 1, pp. 97-100, doi: 10.1017/S1049096510001940.

[6] G. J. Jacobson, "Money in congressional elections," Elect. Stud., vol. 2, no. 2, 1983, doi: 10.1016/0261-3794(83)90067-7.

[7] G. C. Jacobson and S. Kernell, "Strategy and Choice in the 1982 Congressional Elections," PS Polit. Sci. Polit., vol. 15, no. 3, 1982, doi: 10.1017/S1049096500060479. 
[8] M. B. Coate, "A test of political control of the bureaucracy: The case of mergers," Econ. Polit., vol. 14, no. 1, 2002, doi: 10.1111/1468-0343.00097.

[9] Tim Peneliti Perludem, "Menata Kembali Pengaturan Pemilukada," 2011, [Online]. Available: http://perludem.org/wp-content/plugins/download-attachments/includes/download.php?id=208.

[10] KPK, "Laporan Studi Potensi Benturan Kepentingan Dalam Pendanaan Pilkada," 2016. [Online] Available: https://aclc.kpk.go.id/wp-content/uploads/2018/07/Laporan-Pendanaan-Pilkada.pdf.

[11] Jatam, "Mewaspadai Ijon Politik Pertambangan pada Pemilukada Serentak 2017," 2017. [Online]. Available: http://www.albayan.ae.

[12] KPK, "Laporan Tahunan KPK 2018 Direktorat Penelitian dan Pengembangan," 2018. [Online]. Available: https://www.kpk.go.id/images/Integrito/LampiranLaptah2019/LITBANG.pdf.

[13] Dinas ESDM Provinsi Kalimantan Timur, "Daftar Izin Usaha Pertambangan Provinsi Kalimantan Timur," Samarinda, 2019.

[14] D. Fossati, "Electoral Dynamics in Indonesia: Money Politics, Patronage and Clientelism at the Grassroots.," vol. 38, no. 2, pp. 321-324, 2016, doi: 10.1355/cs38-2j.

[15] E. Aspinall and W. Berenschot, Democracy for Sale: Elections, Clientelism, and the State in Indonesia. Cornell University Press, 2019.

[16] R. Marino, O., Subagiyo, H., \& Alamanda, "Masyarakat sipil mengawasi alam: Review izin Industri berbasis lahan," Jakarta, 2013.

[17] Ditjen Minerba, "Keputusan Menteri ESDM tentang Penetapan Kebutuhan dan Persentase Minamal Penjualan Batubara Untuk Kepentingan Dalam Negeri 2018,” 2017.

[18] A. P. Praja, "Potensi pajak hilang triliunan: KPK nilai buruk pengelolaan mineral dan batu bara," Kompas, Jakarta, p. 5, Apr. 24, 2014.

[19] D. Acemoglu and J. Robinson, "Why Nations Fail: The Origins of Power," Prosper. Poverty, Crown Business, New York, 2012.

[20] J. T. Sidel, "Economic foundations of subnational authoritarianism: Insights and evidence from qualitative and quantitative research," Democratization, vol. 21, no. 1, pp. 161-184, 2014, doi: 10.1080/13510347.2012.725725.

[21] S. Risal, D. Paranoan, and S. Djaja, "Analisis Dampak Kebijakan Pertambangan Terhadap Kehidupan Sosial Ekonomi Masyarakat Di Kelurahan Makroman,” eJournal Adm. Reform, vol. 1, no. 3, pp. 516-530, 2017.

[22] S. Risal, S. Zauhar, S. Sarwono, and H. Hermawan, "Impact of Decentralization in East Kalimantan Province on Mineral and Coal Mining Policy,” J. Public Adm. Stud., vol. 005, no. 01, 2020, doi: 10.21776/ub.jpas.2020.005.01.6. 